\author{
Mirosław Wlodarczyk \\ Społeczna Wyższa Szkoła Przedsiębiorczości \\ i Zarządzania w Łodzi \\ Jerzy Janczewski \\ Akademia Humanistyczno-Ekonomiczna \\ w Łodzi
}

\title{
Integrowanie przedsiębiorczości i procesu kształcenia mechaników samochodowych
}

Polska jest krajem o jednym z największych i stale rosnących parków samochodowych w Unii Europejskiej - co 15 samochód jeżdżący po unijnych drogach jest zarejestrowany w naszym kraju (Frelichowski 2010). Liczba zarejestrowanych samochodów osobowych w Polsce stale rośnie, przy czym zakupy nowych samochodów stanowią zdecydowaną mniejszość. Polacy preferują tanie, używane samochody oraz często korzystają z możliwości sprowadzenia z Europy Zachodniej samochodu mającego więcej niż 10 lat. Według danych Instytutu Samar, w czerwcu 2011 roku zarejestrowano w Polsce 24776 nowych samochodów osobowych i 60582 samochodów osobowych pochodzących z prywatnego importu. Wśród importowanych samochodów najwięcej liczyło więcej niż 10 lat (47,56\%). Samochody osobowe liczące od 4 do 10 lat stanowiły 43,80\% prywatnego importu, natomiast najmłodsze, do 4 lat, zaledwie $8,64 \%$.

Eksploatacja tanich, używanych samochodów wymaga intensywnej obsługi i wielu napraw, zatem zawód mechanika samochodowego przez wiele lat będzie popularny, a szkoły kształcące $\mathrm{w}$ zawodzie mechanik samochodowy lub w innych zawodach związanych $\mathrm{z}$ motoryzacją jeszcze długo będą miały uczniów. Celem artykułu jest wskazanie roli i znaczenia zintegrowania przedsiębiorczości i procesu kształcenia właśnie w zawodzie mechanika samochodowego.

\section{Edukacja mechaników samochodowych}

Edukacja jest terminem szerokim i może być interpretowana rozmaicie. W klasycznym ujęciu oznacza ogół procesów oświatowo-wychowawczych, obejmujących kształcenie, wychowanie i szeroko pojmowaną oświatę (Okoń 1984). Zatem edukacja może być między innymi rozumiana jako zdobywanie wiedzy w szkole i poza nią oraz jako kształcenie, czyli ogół czynności i procesów towarzyszących przekazywaniu wiedzy, kształtowaniu określonych cech i określonych umiejętności. Można rozróżnić kilka form edukacji (ryc. 1), mianowicie: edukację formalną, nieformalną, nieoficjalną i akcydentalną, przy czym dwie ostatnie są rodzajami edukacji nieformalnej (Borys 2010). Formy te mogą być równoległe i wzajemnie się uzupełniać. 
Ryc. 1. Formy edukacji mechanika samochodowego

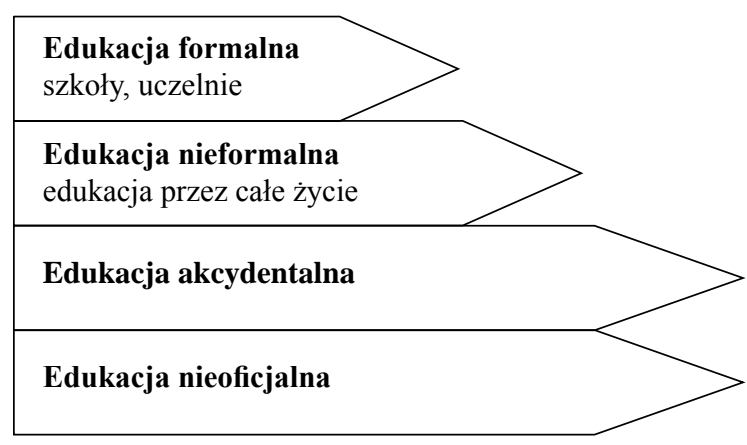

Źródło: opracowanie własne autorów.

Edukacja formalna definiowana jest poprzez odpowiednie standardy i potwierdzana świadectwem lub dyplomem, odbywa się w szkołach lub na wyższych uczelniach, zalicza się do niej szkolenie zawodowe, które dostarcza więcej praktycznej wiedzy. Charakterystyczną cechą formalnej edukacji jest relacja pionowa pomiędzy posiadaczem wiedzy a słuchaczem (uczniem) (tab. 1). Zazwyczaj obok oficjalnego procesu nauczania istnieje edukacja nieoficjalna dająca praktyczną wiedzę z obecności albo w szkole, albo w miejscu pracy, domu, sieciach blogowych, na spotkaniach kół zainteresowań, organizacji młodzieżowych, grup dyskusyjnych czy też wycieczkach szkolnych. Edukacja nieoficjalna w przeciwieństwie do edukacji formalnej nie prowadzi do otrzymania sformalizowanych świadectw, dyplomów lub certyfikatów - tego typu aktywność edukacyjna towarzyszy rozwojowi osobowemu i może być kreowana także przez same osoby uczące się.

Jedną z możliwości zdobycia formalnych kwalifikacji mechanika samochodowego jest ukończenie trzyletniej zasadniczej szkoły zawodowej i zdanie państwowego egzaminu, po którym otrzymuje się certyfikat potwierdzający kwalifikacje zawodowe w zawodzie mechanik samochodowy. Zasadnicze szkoły zawodowe kształcące mechaników samochodowych są bardzo popularne wśród męskiej części młodzieży pragnącej zdobyć atrakcyjny zawód, gdyż samochody dla większości młodzieży stanowią pasję, kojarzą się z popularnym zawodem kierowcy, a niektóre szkoły pomagają zdobyć wymarzone przez młodzież prawo jazdy.

Edukacja formalna jako proces typowej edukacji szkolnej, prowadzący do uzyskania dyplomów, certyfikatów czy zaświadczeń, współcześnie w zawodzie mechanika samochodowego jest już niewystarczająca. Coraz bardziej na znaczeniu zyskuje tu edukacja nieformalna, określana mianem nauki przez praktykę, która trwa przez całe życie człowieka i polega na kształtowania jego postaw, wartości, umiejętności i wiedzy na podstawie różnych doświadczeń codziennego życia oraz wpływu edukacyjnego otoczenia (mody, znajomych, środowiska pracy, rynku). Tutaj zazwyczaj nie ma wykładowców ani nauczycieli dostarczających wiedzy. Edukacja nieformalna mechanika samochodowego może odbywać się równolegle $\mathrm{z}$ edukacją szkolną, na przykład podczas praktyk zawodowych w serwisach samochodowych, studiowania prasy fachowej, wycieczek do zakładów motoryzacyjnych lub na wystawy i targi branżowe, obserwację i podglądanie pracy innych. Obejmuje ona także komunikację interpersonalną, asertywność, autoprezentację i odkrywanie zasobów ukierunkowane przede wszystkim na kształcenie u mechanika umiejętności niezbędnych w życiu społecznym, zwłaszcza w relacjach z innymi ludźmi, na przykład z klientami, dostawcami lub konkurentami warsztatu. Do edukacji nieformalnej zaliczyć można także samodzielną naukę umiejętności korzystania z różnych 
technologii, chociażby z komputera, Internetu i innych środków masowej komunikacji, niezbędnych do aktywności zawodowej.

Tab. 1. Wskaźniki charakteryzujące edukację formalną i nieformalną

\begin{tabular}{|c|c|c|}
\hline Wskaźniki & $\begin{array}{l}\text { Edukacja formalna: } \\
\text { szkoła, studia akademickie, szkolenie zawodowe }\end{array}$ & Edukacja nieformalna \\
\hline $\begin{array}{l}\text { Metody } \\
\text { nauczania, } \\
\text { relacje }\end{array}$ & $\begin{array}{l}\text { Relacja pionowa nauczyciel-uczeń, w szkoleniu } \\
\text { zawodowym kursy przeplatają się z praktyką }\end{array}$ & $\begin{array}{l}\text { Interaktywna relacja } \\
\text { pomiędzy uczniami } \\
\text { i ich środowiskiem - } \\
\text { uczenie się poprzez } \\
\text { praktykę }\end{array}$ \\
\hline Treści & $\begin{array}{l}\text { Ogólna lub nastawiona na umiejętności praktyczne, } \\
\text { określona przez władze edukacyjne }\end{array}$ & $\begin{array}{l}\text { Wybierana przez } \\
\text { uczącego się, nabycie } \\
\text { konkretnych doświad- } \\
\text { czeń }\end{array}$ \\
\hline $\begin{array}{l}\text { Certyfikaty, } \\
\text { dyplomy, } \\
\text { świadectwa }\end{array}$ & $\begin{array}{l}\text { Spełnienie zdefiniowanych kryteriów, pozytywna } \\
\text { weryfikacja wiedzy }\end{array}$ & $\begin{array}{l}\text { Brak certyfikatu, ale } \\
\text { może się zaliczać do } \\
\text { studiów uniwersytec- } \\
\text { kich (np. w Finlandii) }\end{array}$ \\
\hline $\begin{array}{l}\text { Czas trwania } \\
\text { edukacji }\end{array}$ & $\begin{array}{l}\text { Długi, szkolnictwo podstawowe, gimnazjalne, średnie, } \\
\text { uniwersyteckie - około 16-18 lat, szkolenie zawodowe- } \\
\text { krótki 2-3 lata po gimnazjum, 3,5 roku studia inżynier- } \\
\text { skie po szkole średniej. }\end{array}$ & $\begin{array}{l}\text { Edukacja przez całe } \\
\text { życie }\end{array}$ \\
\hline Zalety & $\begin{array}{l}\text { Obowiązkowa edukacja dla wszystkich (do } 18 \text { roku } \\
\text { życia), dostarcza podstawowej wiedzy. Bezpłatna } \\
\text { w sektorze publicznym. Zaświadczenie w formie } \\
\text { oficjalnych świadectw, certyfikatów kompetencji } \\
\text { zawodowych, dyplomów akademickich, szkolenie } \\
\text { zawodowe zapewnia umiejętności praktyczne, które } \\
\text { można wykorzystać bezpośrednio na rynku pracy }\end{array}$ & $\begin{array}{l}\text { Dostępna we wszyst- } \\
\text { kich momentach życia, } \\
\text { kolejna szansa } \\
\text { na zdobywanie wiedzy, } \\
\text { doceniana przez } \\
\text { dojrzałych pracodaw- } \\
\text { ców }\end{array}$ \\
\hline Wady & $\begin{array}{l}\text { Świadectwa szkolne, dyplomy mogą mieć charakter } \\
\text { ogólny, wymagane mogą być dalsze specjalistyczne } \\
\text { studia lub szkolenia zawodowe. Szkoły zawodowe nie } \\
\text { zawsze są wybierane przez młodych ludzi, ale niejako } \\
\text { narzucone przez okoliczności, sytuację ekonomiczną, } \\
\text { ofertę środowiska. Potrzeby rynku pracy mogą się } \\
\text { zmieniać sprawiając, że nabyte kwalifikacje w przyszłości } \\
\text { stają się bezużyteczne }\end{array}$ & $\begin{array}{l}\text { Trudna do formalnego } \\
\text { uznania }\end{array}$ \\
\hline
\end{tabular}

Źródło: opracowanie własne na podstawie M.-B.Benoit.

Po zakończeniu edukacji szkolnej i podjęciu pracy mechanik samochodowy musi uzupełniać swoją wiedzę, na przykład poprzez uczestnictwo w różnorodnych szkoleniach organizowanych przez zakłady pracy, izby rzemieślnicze, dystrybutorów części lub wyspecjalizowane jednostki, potrzebuje on także kontaktu i wymiany doświadczeń z kolegami z branży. Gdy na oficjalne szkolenia lub spotkania połączone z dyskusją i wymianą doświadczeń brakuje czasu czy nawet pieniędzy, a trudne przypadki wymagające szczegółowej wiedzy trzeba rozwiązywać niemal 
od ręki - najczęściej pod presją zniecierpliwionego klienta - wtedy z pomocą przychodzi Internet wraz ze swymi niemal nieograniczonymi możliwościami. Mechanicy samochodowi mogą uczestniczyć w różnorodnych społecznościach skupiających ich według specjalności, a także marek samochodów, mają też do dyspozycji wirtualne programy szkoleniowe. Przykładem mogą być tutaj różne fora dla mechaników, służące wymianie motoryzacyjnych doświadczeń oraz zadawaniu pytań w zakresie mechaniki, diagnostyki, silników benzynowych, silników diesla czy elektroniki samochodowej. Podobną rolę odgrywają platformy do nauki e-learningowej, takie jak aplikacja firmy NGK Spark Plug Europe, która umożliwia mechanikowi samodzielne zapoznawanie się z czterema grupami produktów firmy NGK krok po kroku lub w dowolnej kolejności. Każda z tych czterech części poprowadzi go od podstaw po wiedzę specjalistyczną o świecach zapłonowych, żarowych, czy też sondach lambda. Zrozumiały język, trójwymiarowe obrazy i animacje oraz filmy video i elementy interaktywne objaśniane przez lektora ułatwiają przyswajanie informacji. Użytkownikowi aplikacji towarzyszy także przewodnik w postaci charakterystycznego mechanika, który wskazuje najważniejsze elementy, udziela praktycznych porad i uprzyjemnia naukę. W aplikacji tej można znaleźć dużo ciekawostek i innowacji. Użytkownik może zalogować się do chronionego hasłem konta i korzystać z dodatkowych możliwości, na przykład sprawdzania, którą część aplikacji już opanował, a z którymi częściami jeszcze się nie zapoznał. Zarejestrowani użytkownicy mogą nawet sprawdzić swoją wiedzę w quizach zamieszczonych na końcu każdej sekcji. Pozytywny wynik uzyskany z wszystkich czterech części uprawnia do wydrukowania imiennego certyfikatu.

Praca mechanika samochodowego wymaga stałego śledzenia postępu w motoryzacji, ciągłej nauki, poznawania nowych modeli i nowych rozwiązań konstrukcyjnych samochodów, mechanik musi też stale nadążać za nowoczesnymi technologiami napraw i obsługi. Samochód składa się przeciętnie z około 12 tys. różnych elementów współpracujących ze sobą, mechanik samochodowy musi nie tylko umieć zdiagnozować i wymienić uszkodzony element, ale także wśród wielu ofert części wybrać część od właściwego producenta tak, aby w długim okresie czasu zapewniła jego sprawna prace.

W zdobywaniu wiedzy przez mechaników samochodowych duże znaczenie mają też procesy tzw. edukacji akcydentalnej (ad hoc), spontanicznej, wynikające z codziennych sytuacji w szkole lub w warsztacie, niepowtarzalne, nieplanowane, które wydarzyły się niespodziewanie, ale były źródłem cennej wiedzy dla mechanika. Na przykład poznanie rzadko spotykanego modelu samochodu, analiza innych niż dotychczas wymagań obsługowych, nietypowe przyczyny usterek, nietypowe uszkodzenia, nietypowe technologie lub zmienne i nieoczekiwane zachowanie klienta. Na tym etapie edukacji z codziennych niespodziewanych sytuacji wyciąga się wnioski do dalszego działania.

Konieczność jednoczesnego korzystania przez mechaników samochodowych ze wszystkich form edukacji jest wynikiem postępu w motoryzacji i ewoluującego przemysłu samochodowego. Zmiany niemal w każdym obszarze aktywności mechanika samochodowego zachodzą z dnia na dzień, wymuszając doskonalenie umiejętności i zdobywanie nowej wiedzy. Chociaż nabyte w szkole podstawy z budowy samochodu nadal pozostają takie same, to samochód jest stale na nowo odkrywany choćby poprzez konieczność oszczędzania paliw pierwotnych, wprowadzanie elektrycznego napędu i restrykcyjne ograniczenia emisji spalin. Współczesny mechanik samochodowy oprócz zasad mechaniki musi znać działanie zaawansowanych technologicznie elementów samochodu bazujących na elektronice, niezbędna jest więc podstawowa znajomość zagadnień, które dostarcza stosunkowo młoda dziedzina nazywana mechatroniką. 
Możemy w tym miejscu postawić hipotezę, że proces edukacji jest integralnie powiązany z przedsiębiorczością, w tym z procesem kształcenia postaw przedsiębiorczych. Warunkiem osiągania sukcesów w życiu zawodowym jest uzyskanie pożądanego poziomu integracji obu składowych, zaś celem tejże integracji jest wartość dodana (w realizacji na przykład usługi napraw samochodu). Model wartości dodanej w warunkach integrowania procesu edukacji i kształcenia postaw przedsiębiorczych pokazano na rycinie 2 .

Ryc. 2. Model wartości dodanej w warunkach integrowania procesu edukacji i kształcenia postaw przedsiębiorczych

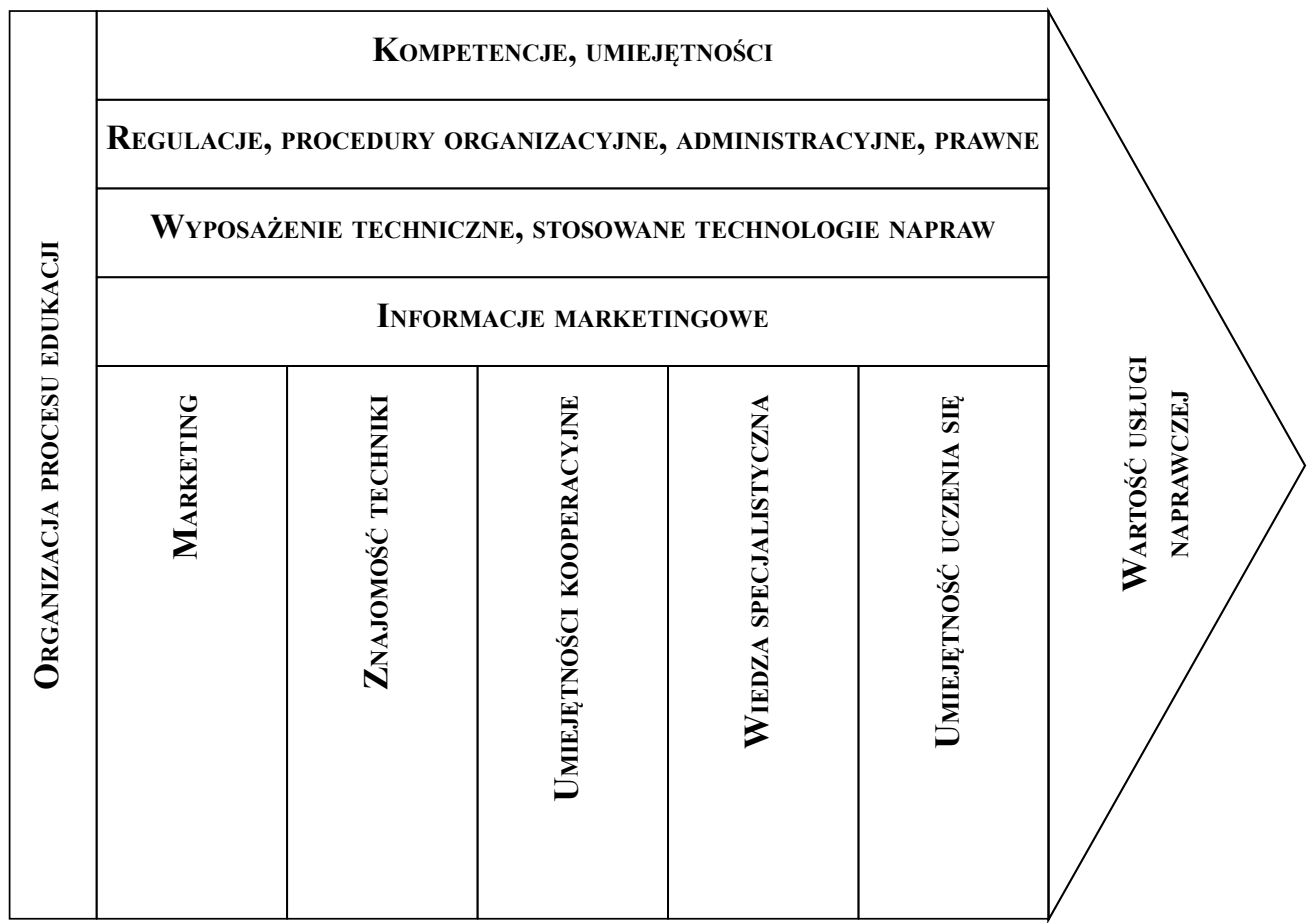

Źródło: opracowanie własne autorów na podstawie: Porter 2001, s. 391.

Mechanicy samochodowi przeważnie się specjalizują - oprócz samochodów osobowych zajmują się też motocyklami, autobusami i samochodami użytkowymi. Specjalizacje obejmują coraz częściej zespoły samochodu, usługi lub samochody z danego kraju (np. francuskie czy japońskie) od danego producenta (Opel, Toyota, Fiat), a nawet z określonego segmentu. Do przeszłości należą już mechanicy tzw. złote raczki, którzy są w stanie naprawić wszystko przy użyciu podstawowych narzędzi i jednocześnie znają się na wszystkim. Praca mechanika samochodowego wymaga zatem wszystkich form edukacji, konieczna jest też tutaj przedsiębiorczość nie tylko rozumiana jako proces zakładania i tworzenia nowego przedsiębiorstwa, ale również, a w zasadzie - przede wszystkim - jako cnota człowieka i jego dążność do stałego uczenia się i doskonalenia własnych umiejętności. 


\section{Przedsiębiorczość w edukacji formalnej}

Podstawowa wiedza o przedsiębiorczości w edukacji szkolnej przekazywana jest na lekcjach z podstaw przedsiębiorczości. Przedmiot ten ma na celu połączyć wiedzę ekonomiczną z wiedzą psychologiczną, wiedzą z zakresu nauk o zarządzaniu i szeroko rozumianą wiedzą społeczną. Pomaga on także odkryć i głębiej poznać własny potencjał przedsiębiorczy, zrozumieć zjawiska zachodzące na mapie gospodarczej regionu, kraju i świata oraz uzmysłowić konieczność zmian - innowacji w gospodarce oraz potrzebę inwestowania poprzez doskonalenie siebie i własnego warsztatu pracy. Ogólne i wychowawcze cele nauczania podstaw przedsiębiorczości prezentuje tabela 2, w której zestawiono przykładowe działania przedsiębiorcze wynikające $\mathrm{z}$ kształtowanych $\mathrm{w}$ ramach podstaw przedsiębiorczości pożądanych umiejętności przyszłych mechaników samochodowych.

Ogólnym celem formalnego kształcenia w zakresie przedmiotu podstawy przedsiębiorczości jest przygotowanie do aktywnego uczestnictwa w życiu gospodarczym w warunkach gospodarki rynkowej. Przystosowaniu temu sprzyja wyrobienie takich umiejętności, jak umiejętność poszukiwania i praktycznego stosowania wiedzy, umiejętność doskonalenia się, umiejętność myślenia i działania, umiejętność komunikowania się i kierowania własnymi emocjami. Proces nauczania przedmiotu podstawy przedsiębiorczości służy także osiąganiu celów wychowawczych poprzez kształtowanie postawy przedsiębiorczości i kreatywności, postawy uczciwości i rzetelnej pracy, odpowiedzialności, samodoskonalenia i samorealizacji, solidarności międzyludzkiej oraz poszanowania środowiska naturalnego. Osiągniecie wszystkich wymienionych celów powinno przełożyć się na przedsiębiorcze działania mechaników samochodowych w przyszłych ich miejscach pracy, na przykład warsztatach samochodowych, i powiększać potencjał przedsiębiorczości tych warsztatów.

\section{Przedsiębiorczość w małym warsztacie samochodowym}

Przedsiębiorczość w małych warsztatach samochodowych przejawia się miedzy innymi w zakładaniu, rozwijaniu i prowadzeniu działalności polegającej na świadczeniu samochodowych usług naprawczych. Działalność taka powinna charakteryzować się następującymi elementami: przynosić zysk, tworzyć nowy wyrób lub usługę i umożliwiać osiąganie korzyści przez przedsiębiorcę i pracowników. Ważnymi wyróżnikami przedsiębiorczości są: rozpoznawanie i wykorzystywanie szans i okazji, pokonywanie niepewności, ustawiczna aktywność właściciela i pracowników, powstawanie sieci wzajemnych powiązań i współpracy, umiejętność wykorzystywania zasobów, długofalowa wizja działalności. Cechy firmy przedsiębiorczej - na przykładzie małego warsztatu samochodowego - przedstawiono na rycinie 3.

Ryc. 3. Wyróżniki przedsiębiorczości małej firmy

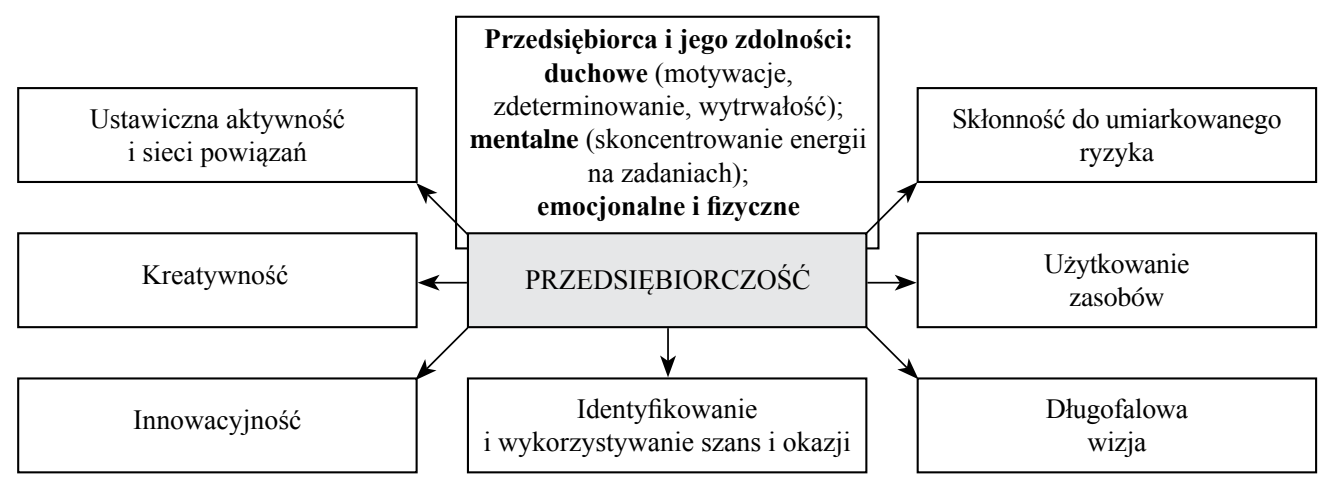

Źródło: opracowanie własne na podstawie przeglądu definicji przedsiębiorczości. 
Tab. 2. Cele nauczania przedmiotu podstawy przedsiębiorczości

\begin{tabular}{|c|c|c|}
\hline \multirow{7}{*}{ 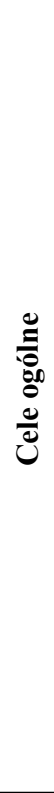 } & Umiejętność & Przykładowe działania ksztaltujące umiejętności \\
\hline & poszukiwanie wiedzy & $\begin{array}{l}\text { poszukiwanie, wybór, analizowanie, gromadzenie, porządkowanie } \\
\text { i selekcja, praktyczne stosowanie }\end{array}$ \\
\hline & doskonalenie się & $\begin{array}{l}\text { poznanie samego siebie, uświadomienie własnych możliwości } \\
\text { i poznanie sposobów ich wykorzystania, dochodzenie do własnego } \\
\text { systemu doskonalenia się }\end{array}$ \\
\hline & myślenie & $\begin{array}{l}\text { analizowanie sytuacji, rozwiązywanie problemów, podejmowanie } \\
\text { decyzji, stosowanie metod, technik i narzędzi kreatywnego myślenia, } \\
\text { samodzielność myślenia }\end{array}$ \\
\hline & działanie & $\begin{array}{l}\text { planowanie i organizowanie pracy, zarządzanie czasem, samokontrola } \\
\text { i ocenianie rezultatów, wybór priorytetów, wybór właściwego } \\
\text { kierunku, praca w grupie }\end{array}$ \\
\hline & komunikowanie się & $\begin{array}{l}\text { posługiwanie się mową ciała, aktywne słuchanie, empatia, prezento- } \\
\text { wanie, negocjowanie, rozwiązywanie konfliktów, praca w zespole, } \\
\text { przemawianie, budowanie sieci kontaktów }\end{array}$ \\
\hline & $\begin{array}{l}\text { kierowanie się } \\
\text { własnymi emocjami }\end{array}$ & $\begin{array}{l}\text { rozumienie swoich uczuć, wyzwalanie wewnętrznego potencjału, } \\
\text { radzenie sobie ze stresem, wywieranie wpływu na innych }\end{array}$ \\
\hline \multirow{7}{*}{ 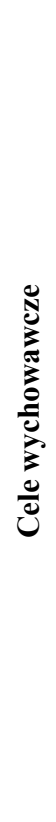 } & $\begin{array}{l}\text { przedsiębiorczość } \\
\text { i kreatywność }\end{array}$ & $\begin{array}{l}\text { przedsiębiorczość jako cnota, cecha i proces, aktywna postawa } \\
\text { w zdobywaniu środków do życia, generowanie pomysłów, zarządzanie } \\
\text { zmianą }\end{array}$ \\
\hline & uczciwość & $\begin{array}{l}\text { uznawanie norm moralnych i reguł postępowania, przestrzeganie } \\
\text { zasad uczciwej konkurencji, dotrzymywanie umów, terminowe } \\
\text { wywiązywanie się ze zobowiązań finansowych, nienaruszanie } \\
\text { własności firmy, chronienie tajemnicy. }\end{array}$ \\
\hline & rzetelna praca & $\begin{array}{l}\text { punktualność, zaangażowanie, rzetelne wypełnianie swoich } \\
\text { obowiązków }\end{array}$ \\
\hline & odpowiedzialność & $\begin{array}{l}\text { odpowiedzialność za produkt, bezpieczeństwo, zdrowie, jakość pracy, } \\
\text { odpowiedzialność społeczna }\end{array}$ \\
\hline & $\begin{array}{l}\text { samodoskonalenie } \\
\text { i samorealizacja }\end{array}$ & $\begin{array}{l}\text { podnoszenie kwalifikacji, podwyższanie kompetencji, rozwijanie } \\
\text { zdolności i talentów, doskonalenie umiejętności pracy w zespole } \\
\text { i komunikowania się z innymi }\end{array}$ \\
\hline & $\begin{array}{l}\text { solidarność } \\
\text { międzyludzka }\end{array}$ & $\begin{array}{l}\text { docenianie osiągnięć współpracowników, uczciwa płaca, tworzenie } \\
\text { nowych miejsc pracy }\end{array}$ \\
\hline & $\begin{array}{l}\text { ochrona środowiska } \\
\text { naturalnego }\end{array}$ & $\begin{array}{l}\text { oszczędność materiału, paliwa, energii, niezanieczyszczanie } \\
\text { środowiska, poszanowanie praw zwierząt }\end{array}$ \\
\hline
\end{tabular}

Źródło: opracowanie własne autorów z inspiracji: Lewańczyk T.

Przedsiębiorczość małych warsztatów samochodowych, podobnie jak przedsiębiorczość wszystkich mikro- i małych firm, można rozpatrywać w kilku płaszczyznach: na gruncie ich ekonomicznych działań, bazując na cechach osobowych i charakterystyce przedsiębiorcy, traktując przedsiębiorczość jako rodzaj menedżerskiego zachowania i specyficzny sposób zarządzania oraz uwzględniając w szerokim znaczeniu czynniki społeczno-kulturowe 
(Janczewski 2005). O przedsiębiorczości małego warsztatu decydują także zatrudnieni w nim pracownicy - wykonywanie naprawy lub obsługi samochodu to część niewidzialna usługi, klient zlecający taką usługę zdany jest na działanie, uczciwość, rzetelność i odpowiedzialność mechanika, od którego wyników pracy w dużej mierze zależy bezpieczeństwo klienta jak i pozostałych uczestników ruchu drogowego. O złożoności przedsiębiorczości decyduje wiele czynników, które wpływają na działania przedsiębiorcze zarówno pracowników, jak i właściciela warsztatu samochodowego, a przede wszystkim na efekty tych działań. Oczekiwane efekty (korzyści) z procesu przedsiębiorczości, zatem i cele małego warsztatu samochodowego, wskazują na takie obszary związane z jego funkcjonowaniem, jak: marketing, wizerunek, innowacje, jakość, zasoby, rentowność i odpowiedzialność publiczna. Przykładowe działania przedsiębiorcze i ich rezultaty wynikające $\mathrm{z}$ wymienionych obszarów przedstawiono $\mathrm{w}$ tabeli 3. Efektywność tych działań przede wszystkim zależy od edukacji i osiągnięcia już na etapie edukacji formalnej celów ogólnych i celów wychowawczych przekazywanych między innymi na lekcjach z podstaw przedsiębiorczości. Uzyskane w rezultacie edukacji szkolnej umiejętności są później przydatne mechanikowi w każdej dziedzinie funkcjonowania warsztatu samochodowego zarówno na poziomie właściciela-menedżera, jak i na poziomie pracownika.

Pojęcie przedsiębiorczość jest pojęciem lotnym, szeroko rozumianym i różnie interpretowanym, najczęściej w zależności od okoliczności i bieżących potrzeb. Przedsiębiorczość traktowana jako cecha właściciela i pracowników firmy (zwłaszcza mikro- lub małej) oraz ich przedsiębiorcze działania mają decydujący wpływ na wizerunek warsztatu samochodowego w otoczeniu, działania marketingowe, zasoby warsztatu, wprowadzane w nim zmiany, jakość świadczonych usług, rentowność i odpowiedzialność publiczną. Wizerunek warsztatu w otoczeniu przejawia się dbałością pracowników o miejsce świadczenia usługi, estetyczny wygląd zewnętrzny i ład w firmie, ugruntowaną tożsamość firmy, posiadanie rekomendacji od ważnych klientów, posiadanie dobrej reputacji u klientów i dostawców. Działania marketingowe przejawiają się w śledzeniu zachowań konkurencji, systematycznym określaniu własnej pozycji na rynku i poszukiwaniu luk i nisz rynkowych, określaniu zapotrzebowania na nowe usługi, działaniach promocyjnych, segmentacji, współpracy i komunikacji z klientem oraz wykorzystaniem różnorodności ofert dostawców. Warsztat przedsiębiorczy to warsztat o bogatych zasobach zarówno materialnych, jak i niematerialnych. Działania przedsiębiorcze warsztatu w obszarze zasobów to inwestowanie w wyposażenie, wykorzystanie zewnętrznych zasobów, na przykład poprzez outsourcing, ustawiczne dokształcanie się pracowników i właściciela, stymulowanie i wykorzystanie zaradności i inicjatywy pracowników, współpraca z innymi firmami, w tym z konkurencją. Innowacje są podstawowym narzędziem przedsiębiorczości, nie koniecznie muszą to być tzw. innowacje twarde - działalność innowacyjna warsztatów samochodowych może przejawiać się wprowadzaniem nowych procedur, usprawnień, produktów i usług oraz technologii obsługi i naprawy samochodów. Działania przedsiębiorcze w obszarze jakości usług naprawczych to specjalizacja w wybranych usługach, autoryzacja uznanej marki, wdrażanie lub stosowanie formalnych lub nieformalnych systemów jakości, doskonalenie procedur oraz monitorowanie poziomu satysfakcji klientów. Rentowność ma decydujący wpływ na inwestowanie oraz zadowolenie właściciela i pracowników z pracy, konieczne w tym obszarze działania to zapewnienie efektywności działania warsztatu poprzez właściwy dobór metod, narzędzi, redukowanie zbędnych kosztów związanych ze świadczeniem usług, redukowaniem wszelkich niesprawności, pozyskiwanie kapitału na rozwój warsztatu. Równie ważna jest odpowiedzialność publiczna warsztatu, a działania w tym obszarze to współpraca z regionem miejscem lokalizacji firmy, praca na rzecz tego regionu, zrzeszanie się zarówno poziome, jak i pionowe, dbałość o środowisko naturalne, tworzenie nowych miejsc pracy i patronowanie szkołom zawodowym. 
Tab. 3. Przykładowe efekty działań przedsiębiorczych małych warsztatów

\begin{tabular}{|c|c|c|}
\hline $\begin{array}{l}\text { Obszary } \\
\text { funkcjonowa- } \\
\text { nia warsztatu }\end{array}$ & $\begin{array}{c}\text { Działania przedsiębiorcze małych warsztatów } \\
\text { samochodowych }\end{array}$ & Efekty dzialań \\
\hline Marketing & $\begin{array}{l}\text { Śledzenie zachowań konkurencji, określanie własnej } \\
\text { pozycji na rynku, poszukiwanie luk i nisz rynkowych, } \\
\text { określanie zapotrzebowania na nowe usługi, promocje, } \\
\text { komunikacja i współpraca z klientem, współpraca ze } \\
\text { stałym klientem, wykorzystanie różnorodności ofert } \\
\text { dostawców }\end{array}$ & $\begin{array}{l}\text { Umiejętność dokonania } \\
\text { analizy otoczenia, } \\
\text { analizy benchmarkin- } \\
\text { gowe, poszukiwanie } \\
\text { nowych segmentów } \\
\text { rynku }\end{array}$ \\
\hline Wizerunek & $\begin{array}{l}\text { Kształtowanie pozytywnego wizerunku warsztatu, dbałość } \\
\text { o miejsce świadczenia usługi, wygląd zewnętrzny i tożsa- } \\
\text { mość firmy, zdobywanie rekomendacji od ważnych klien- } \\
\text { tów, dbanie o dobrą reputację u klientów i dostawców }\end{array}$ & $\begin{array}{l}\text { Poprawa wizerunku } \\
\text { firmy, umacnianie jej } \\
\text { pozycji rynkowej }\end{array}$ \\
\hline Innowacje & $\begin{array}{l}\text { Wprowadzanie nowych produktów i usług, wprowadza- } \\
\text { nie nowych technologii, wprowadzanie nowych procedur } \\
\text { i usprawnień w każdej dziedzinie aktywności warsztatu }\end{array}$ & $\begin{array}{l}\text { Poszerzanie asortymen- } \\
\text { tu usług, wzrost } \\
\text { zadowolenia klientów }\end{array}$ \\
\hline Jakośćć & $\begin{array}{l}\text { Specjalizacja w określonych usługach, autoryzacja } \\
\text { uznanej marki, wdrażanie lub stosowanie systemów } \\
\text { jakości, doskonalenie procedur, monitorowanie satysfak- } \\
\text { cji klientów }\end{array}$ & $\begin{array}{l}\text { Możliwość zajęcia } \\
\text { wiodącej pozycji na } \\
\text { danym rynku, uzyska- } \\
\text { nie certyfikatów jakości }\end{array}$ \\
\hline Zasoby & $\begin{array}{l}\text { Inwestowanie w wyposażenie warsztatu, wykorzystanie } \\
\text { zewnętrznych zasobów, ustawiczne dokształcanie się, } \\
\text { opracowywanie własnych procedur, stymulowanie } \\
\text { i wykorzystanie zaradności i inicjatywy pracowników, } \\
\text { współpraca z innymi firmami }\end{array}$ & $\begin{array}{l}\text { Powiększanie zasobów } \\
\text { intelektualnych, } \\
\text { kreowanie nowych } \\
\text { zasobów i lepsze ich } \\
\text { wykorzystanie }\end{array}$ \\
\hline Rentowność & $\begin{array}{l}\text { Zapewnienie efektywności działania warsztatu, reduko- } \\
\text { wanie kosztów związanych ze świadczeniem usług } \\
\text { redukowanie niesprawności, pozyskiwanie kapitału } \\
\text { na rozwój firmy }\end{array}$ & $\begin{array}{l}\text { Wzrost zysków, } \\
\text { racjonalne gospodaro- } \\
\text { wanie finansami }\end{array}$ \\
\hline $\begin{array}{l}\text { Odpowiedzial- } \\
\text { ność publiczna }\end{array}$ & $\begin{array}{l}\text { Współpraca z regionem - miejscem lokalizacji firmy, } \\
\text { praca na rzecz regionu, zrzeszanie się poziome i pionowe, } \\
\text { dbałość o środowisko naturalne, tworzenie nowych } \\
\text { miejsc pracy }\end{array}$ & $\begin{array}{l}\text { Budowanie społecznego } \\
\text { wizerunku firmy }\end{array}$ \\
\hline
\end{tabular}

Źródło: opracowanie własne autorów.

Małe warsztaty samochodowe mogą doskonalić swoje umiejętności i kompetencje przez udział w procesie edukacji oraz postawy przedsiębiorcze mechaników, a także włączanie się w relacje z uczestnikami rynku napraw samochodowych. Wysoka konkurencyjność wśród usługodawców powinna zwracać uwagę na lepsze zrozumienie potrzeb klienta i dostosowanie polityki cenowej. Wartość handlowa większości aut osobowych użytkowanych w Polsce jest niska, a ich właściciele oszczędzają na eksploatacji. Jedynie warsztaty utrzymujące koszty swoich usług na poziomie akceptowanym przez użytkowników mogą liczyć na rozwój działalności. Nowe formy edukacji przybliżają atrakcyjne obszary działalności małych warsztatów samochodowych, w tym wykorzystanie technik informatycznych oraz poszukiwanie wiedzy specjalistycznej. Integrowanie procesu edukacji zawodowej i procesu kształtowania postaw przedsiębiorczych mechaników samochodowych staje się obecnie warunkiem niezbędnym do utrzymania pozycji rynkowej firmy z sektora usług naprawczych. 


\section{Literatura}

1. Aceto S., Dondi C., Nascimbeni F., 2010, Vision for Learning in Europe in 2025, „eLearning Papers”, N 18, February, www.elearningpapers.eu (dostęp: 15.09.2011).

2. Benoit M.-B., Edukacja nieformalna jako narzędzie edukacji, youth-partnership-eu.coe.int/youth-partnership/.../T.../5_education.pdf (dostęp: 15.09.2011).

3. Borys T., 2010, Dekada edukacji dla zrównoważonego rozwoju - polskie wyzwania, „Problemy Ekorozwoju", 5/1, s. 59-70, http://ekorozwoj.pol.lublin.pl/no9/f.pdf (dostęp: 15.09.2011).

4. Frelichowski W., 2010, Polska na szóstym miejscu w Unii pod względem liczby samochodów, http:// www.gs24.pl/apps/pbcs.dll/article?AID=/20100201/AUTO/479500672 (dostęp: 10.07.2011).

5. Janczewski J., 2005, Kryteria i miary oceny przedsiębiorczości malej firmy [w:] Przedsiębiorczość a współczesne wyzwania cywilizacyjne, Z. Zioło, T. Rachwał (red.), „Przedsiębiorczość - Edukacja”, nr 1, Zakład Przedsiębiorczości i Gospodarki Przestrzennej Instytutu Geografii Akademii Pedagogicznej im. Komisji Edukacji Narodowej w Krakowie, Wydawnictwo „MiWa”, Kraków, s. 115-120.

6. Janczewski J., 2009, Wiedza jako kryterium oceny przedsiębiorczości małej firmy [w:] Szkoły wyższe kreatorem innowacji w gospodarce, R. Marcinkowski (red.), Oficyna Wydawnicza Politechniki Warszawskiej, Warszawa, s. 49-55.

7. Lalak D., Pilch T. (red.), 1999, Elementarne pojęcia pedagogiki społecznej i pracy socjalnej, Wydawnictwo Akademickie Żak, Warszawa.

8. Lewańczyk T., Rola pracy domowej w nauczaniu przedsiębiorczości w szkole zawodowej, http:// www.profesor.pl/publikacja,10708,Artykuly,Rola-pracy-domowej-w-nauczaniu-przedsiebiorczosciw-szkole-zawodowej (dostęp: 15.09.2011).

9. Nauka i zabawa z nowym E-Learningiem NGK, informacja prasowa, http://www.ngk.de/fileadmin/ templates/Dokumente/PL/Presse/2011/Nowy_E-learning_NGK.pdf (dostęp: 17.07.2011).

10. Okoń W., 1984, Słownik pedagogiczny, wyd. 3, PWN, Warszawa.

11. Porter M.E., 2001, Porter o konkurencji, PWE, Warszawa.

12. Podstawy przedsiębiorczości dla IV etapu edukacyjnego [w:] Podstawa programowa wychowania przedszkolnego oraz kształcenia ogólnego w szkołach podstawowych, gimnazjach i liceach, t. 4, http:// www.men.gov.pl/index.php?option=com_content\&view=article\&id=2064\%3 Apodstawa-programo wa\&catid $=230 \% 3$ Aksztacenie-i-kadra-ksztacenie-ogolne-podstawa-programowa\&Itemid=290.

13. Włodarczyk M., Janczewski J., 2008, Wiedza $w$ rozwoju przedsiębiorczości $w$ matym warsztacie samochodowym [w:] Rola przedsiębiorczości w gospodarce opartej na wiedzy, Z. Zioło, T. Rachwał (red.), „Przedsiębiorczość - Edukacja”, nr 4, wydawnictwo Nowa Era, Zakład Przedsiębiorczości i Gospodarki Przestrzennej Instytutu Geografii Uniwersytetu Pedagogicznego im. Komisji Edukacji Narodowej w Krakowie, Warszawa - Kraków.

\section{Integrating entrepreneurship with educational process used for car mechanics}

Poland is a country with the largest number of cars in the European Union. Furthermore, this number is still growing. Polish people prefer cheap and used cars. They often buy a vehicle imported from the Western Europe that is over 10 years old. Exploitation of used and cheap cars requires a lot of service and repairs hence a car mechanic profession will enjoy popularity for many years ahead. Additionally, schools teaching young people this profession as well as any other profession related to automotive industry shall have many students for a long period of time. The aim of this article is present a role and significance of integrating entrepreneurship with an educational process used for a car mechanic profession. Those integrated processes of vocational education and entrepreneurship is the necessary condition for a company in service-repair market to keep their competitive position. 